\title{
Genomic and biotechnological interventions for crop improvement in cucurbitaceous crops: A review
}

\section{Chet Ram, MK Berwal, JS Gora, R Kumar, SM Haldhar, K \\ Gurjar \& D Singh}

Journal of Agriculture and Ecology

Volume-7 (June, 2019)

ISSN: 2456-9410

\section{Journal of Agriculture}

ISSN: 2456-9410

Volume: 7

Journal of Agriculture and Ecology (2019) 7: 1-15 http://doi.org/10.53911/JAE.2019.7101

\section{and Ecology}




\title{
Genomic and biotechnological interventions for crop improvement in cucurbitaceous crops: A review
}

\author{
Chet Ram§, MK Berwal, JS Gora, R Kumar, SM Haldhar, K Gurjar \& D Singh \\ ICAR-Central Institute for Arid Horticulture, Sri Ganganagar Highway, Beechwal Industrial Area, \\ Bikaner (Rajasthan)-334006, India \\ DCorresponding author: Chet Ram, E-mail: chetram.nbpgr@gmail.com
}

\begin{tabular}{|c|c|}
\hline Article Info & Abstract \\
\hline $\begin{array}{l}\text { Key } \\
\text { Wucurbitaceous } \\
\text { crops, molecular } \\
\text { markers, genetic } \\
\text { transformation, } \\
\text { CRISPR/CAS9. }\end{array}$ & $\begin{array}{l}\text { The cucurbitaceous family has comprised with diverse economically important } \\
\text { cucurbits. It primarily comprised of } 118 \text { genera and } 825 \text { species which being } \\
\text { consumed as food worldwide since the domestication of the plants. In India, } \\
\text { cucurbits are being grown throughout regions of the country including hot semi- } \\
\text { arid and arid zones. With the advent of genomic breakthrough, a large number } \\
\text { of genomic and biotechnological interventions have been developed in } \\
\text { cucurbitaceous crops. The plenty of molecular markers are available in } \\
\text { cucurbits and these markers were deployed to assess the genetic diversity and } \\
\text { mapping of the QTLS/genes of interest. The success in development of genomic } \\
\text { tools may happens by genome sequencing of mostly important cucurbitaceous } \\
\text { crops such as watermelon, cucumber, muskmelon, bottle gourd, pumpkins. } \\
\text { Transgenic and non-transgenic plants were developed in various cucurbitaceous } \\
\text { crops by employing of Agrobacterium-mediated transformation and } \\
\text { CRISPR/CAS9 approach, respectively. Thus cucurbitaceous crops have been } \\
\text { considerably exploited at molecular level and biotechnological interventions } \\
\text { were developed for crop improvement. However, a comprehensive report in } \\
\text { cucurbitaceous crops regarding genomic and biotechnological developments is } \\
\text { not available in public domain. Therefore, in the present review, we have } \\
\text { collected the information related to genomics and biotechnology in cucurbits } \\
\text { and emphasized on some successful interventions. }\end{array}$ \\
\hline
\end{tabular}

Copyright (C2019 Chet Ram et al., This is an open access article published under the terms of the Creative Commons Attribution License, which permits unrestricted use, distribution, and reproduction in any medium, provided the original work is properly cited.

Preferred citation: Chet Ram, Berwal MK, Gora JS, Kumar R, Haldhar SM, Gurjar K \& Singh D. 2019. Genomic and biotechnological interventions for crop improvement in cucurbitaceous crops: A review. Journal of Agriculture and Ecology, 7: 1-15; http://doi.org/10.53911/JAE.2019.7101.

\section{Introduction}

The cucurbitaceous family primarily comprised of 118 genera and 825 species which being consumed as food worldwide since the domestication of the plants. In India, cucurbits are being grown throughout regions of the country including hot semi-arid and arid zones. Globally India occupied $2^{\text {nd }}$ position in the area and production of the cucurbitaceous crops. Cucurbits share about $5.6 \%$ of the total vegetable production of India and according to the FAO (FAOSTAT 2015) estimation, cucurbits are cultivated on about 4,290,000 ha with the productivity of $10.52 \mathrm{t} / \mathrm{ha}$. The cucurbitaceous crops are very important crops for human health. These are being consumed 
as salad (long melon, cucumber, gherkins, etc.), sweet (ash gourd, pumpkins, pointed gourd, etc.), pickles (gherkins), deserts (watermelon and muskmelon) and culinary purpose. Some cucurbits such as bitter gourd pose unique medicinal properties. In the commercial cropping system, cucurbitaceous crops are being cultivated as intercrops. According to an estimate, India will need to produce a large production of vegetables in the future to provide food and nutritional security at individual level and, being a large group of vegetable; cucurbits provide better scope to enhance overall productivity and production (FAOSTAT 2015). There is tremendous genetic diversity within the Cucurbitaceae family, and they can adapt in the range of climate regimes includes tropical and subtropical regions, arid deserts, and temperate regions.

The genetic diversity in cucurbitaceous crops is widen and significantly ranged in the monoploid chromosome number like 7 (Cucumis sativus), 11 (Citrullus spp., Momordica spp., Lagenaria spp., Sechium spp., and Trichosanthes spp.), 12 (Benincasa hispida, Coccinia cordifolia, Cucumis spp. other than C. sativus, and Praecitrullus fistulosus), 13 (Luffa spp.), and 20 (Cucurbita spp.). Among the cucurbits, cucumber, melon, watermelon, pepo and bottle guard are explored for genetic diversity assessment, development of genomic tools and genetic improvement (Bhawna et al. 2014; Park et al. 2015). The genomes of these cucurbits have been sequenced and a genomic database (http://cucurbitgenomics.org) is available for the basis of fundamental and scientific research. The genomic and biotechnological interventions can pave the enhanced utilization of the cucurbits and it can help to identify the genomic tools for agroeconomical importance. However, the admired genomic and biotechnological interventions have been carried out considerably in cucurbit crops. The present scenario deciphers the more interventions on melon genomic and biotechnology for various aspects. However other cucurbits also paid the attention regarding identification of economical genes and development of molecular markers which can enhance the germplasm for molecular breeding. Therefore, we are focusing on some cucurbitaceous crops as a case studies like cucumber, watermelon, pepo, musk melon and bottle gourd which are well described and characterized at molecular levels.

\section{Development of EST database}

The details about gene expression studies against the biotic and abiotic stresses in the cucurbit vegetables are very limited. Thus the progress to generation of ESTs is very steady except with few cases. Consequently, the identification of the genes of interest for a particular trait is directly affected and not much intervention has been formulated in this context. The development of EST database in Cucurbita pepo (Blanca et al. 2011), Cucumis sativus (Guo et al. 2010; Ando \& Grumet, 2010), C. melo (Clepet et al. 2011), Citrulus vulgaris (Guo et al. 2011), etc. make the basis for identification of genes of interest and other important genomic resources. Due to easy accessibility, highly conserved in nature and belong to the 
functional part of the genome, the EST database were utilized for development of gene based molecular markers (FernandezSilva et al. 2008; $\mathrm{Hu}$ et al. 2010; Xu et al. 2011; Kwon et al. 2013; Verma \& Arya, 2015), designing of probes (Wechter et al. 2008), identification of SNPs (Deleu et al. 2009) and for in silico expression analysis of the genes in various cucurbitaceous crops (Zheng et al. 2018). Similarly, the generated EST databases were also utilized in molecular assisted breeding for enhanced utilization of cucurbitaceous germplasm.

\section{Genome sequencing and database}

In the Next-Generation Sequencing (NGS) technique, various modern, highthroughput and sophisticated sequencing technologies are being utilized for sequencing the genome of plants, microbes, etc. These recent technologies lead to sequence the genomes much more robust than the previously used classical sequencing techniques, and as such have revolutionized the study of genomics and molecular biology. In the current era of genomics, a large numbers of crops plants have been sequenced with the advent of NGS technologies. Regarding cucurbitaceous crops, some useful cucurbits have been sequenced in recently for understanding the genetic mechanisms of the useful traits (Table 1). Such genomic interventions may create the scientific opportunity to understand the complex mechanisms related to sex determination, adaptation to adverse climatic conditions, fruits qualities etc.
Cucumber is an economically important crop as well as a model system for sex determination studies and plant vascular biology in cucurbits. To understand the genetic phenomena of these important traits, the draft genome sequence of Cucumis sativus var. sativus L. has been assembled into $367 \mathrm{Mb}$ with 23248 protein coding genes ( $\mathrm{Li}$ et al. 2011). The sequenced cucumber genome made the afford insight into important traits such as its sex expression, disease resistance, biosynthesis of cucurbitacin and fresh green odor. The investigation has identified 686 gene clusters related to vascular function especially phloem function of the plant. This intervention can provide the valuable resource for developing elite cultivars and for studying the evolution and function of the plant vascular system.

Watermelon is an important cucurbit crop grown throughout the world. A highquality draft genome sequence of the watermelon containing 23,440 predicted protein-coding genes has been reported recently (Guo et al. 2013). The genome sequences of watermelon revealed the crop diversification within the species which provided an evolutionary scenario for the origin of the 11 watermelon chromosomes derived from a 7-chromosome paleohexaploid eudicot ancestor. By virtue of sequencing data, genomic regions that were preferentially selected during domestication were identified. It was also reported that various R-genes were lost during domestication in the plant species. In addition, integrative genomic and transcriptomic analyses resulted into important aspects of phloem-based vascular 
signaling in watermelon and cucumber and identified genes which are crucial to play sugar accumulation and citrulline metabolism. With the advent of genome sequencing, the genome-wide identification and detailed characterization of a large number of gene families have been carried out in watermelon (Zhang et al. 2017; Yu et al. 2017). These interventions may make the fundamental and applied research in watermelon for crop improvement against various environmental stresses. Similarly, the genome sequence of melon has been carried out and predicted 27,427 protein-coding genes, which we analyzed by reconstructing 22,218 phylogenetic trees, allowing mapping of the orthology and paralogy relationships among sequenced plant. They have observed the absence of recent whole-genome duplications in the melon lineage. The ancient eudicot triplication and transposon amplification may increase the genome size of the melon as compared to close relative cucumber. A low number of nucleotide-binding leucine-rich repeat (disease resistance genes) were annotated and suggested the existence of specific defense mechanisms in this species. Similarly, the Cucurbita genus contains several economically important species in the Cucurbitaceous family. The report of highquality genome sequences of $C$. maxima and $C$. moschata provided evidence supporting an allotetraploidization event in Cucurbita species (Sun et al. 2017).

The genome sequencing of bottle gourd reported a high-quality $313.4 \mathrm{Mb}$ genome sequence of a bottle gourd inbred line with a scaffold N50 of $8.7 \mathrm{Mb}$ and the longest of $19.0 \mathrm{Mb}$ (Wu el at. 2017). About $98.3 \%$ of the assembled scaffolds are anchored into the 11 pseudomolecules. The comparative genomic analysis identified chromosome-level syntenic relationships between bottle gourd and other cucurbits, as well as lineage-specific gene family expansions in bottle gourd. The sequencing data of bottle gourd were applied to identify and map a dominant monogenic locus, Prs (317.8-kb region on chromosome $01)$ which exclusively confers resistance against Papaya ringspot virus (PRSV) resistance in bottle gourd. A cleaved amplified polymorphic sequence (CAPS) marker tightly linked to the Prs locus has been developed and demonstrated its potential application in marker-assisted selection of PRSV resistance in bottle gourd. This study provides insights into the paleohistory of Cucurbitaceae genome evolution, and the high-quality genome sequence of bottle gourd provides a useful resource for plant comparative genomics studies and cucurbit improvement. Thus, the advent of genome sequences could be useful for other unexploited cucurbits for valuable traits.

Table 1. Genome sequencing of cucurbitaceous crops

\begin{tabular}{|c|c|c|c|c|c|}
\hline Crop & $\begin{array}{l}\text { Botanical } \\
\text { Name }\end{array}$ & $\begin{array}{l}\text { Chromosome } \\
\text { numbers }\end{array}$ & $\begin{array}{l}\text { Genome size } \\
(\mathrm{Mb})\end{array}$ & $\begin{array}{l}\text { Number } \\
\text { Genes }\end{array}$ & References \\
\hline $\begin{array}{l}\text { Cucumber } \\
\text { (Chinese } \\
\text { Long) }\end{array}$ & $\begin{array}{l}\text { Cucumis } \\
\text { sativus }\end{array}$ & 7 & 367 & 23248 & Li et al. 2011 \\
\hline Melon & Сиситis & 13 & 375 & 27427 & Ruggieri et al. \\
\hline
\end{tabular}




\begin{tabular}{|c|c|c|c|}
\hline & melo & & 2018 \\
\hline $\begin{array}{l}\text { Wild } \\
\text { cucumber } \\
\text { (PI 183967) }\end{array}$ & $\begin{array}{l}\text { Cucumis } \\
\text { sativus }\end{array}$ & 23667 & Qi et al. 2013 \\
\hline Watermelon & $\begin{array}{c}\text { Citrullus } \\
\text { lanatus }\end{array}$ & 23440 & Guo et al. 2013 \\
\hline Pumpkin & $\begin{array}{c}\text { Cucurbita } \\
\text { maxima cv. } \\
\text { Rimu }\end{array}$ & 32076 & Sun et al. 2017 \\
\hline Bottle gourd & $\begin{array}{c}\text { Lagenaria } \\
\text { siceraria }\end{array}$ & 22472 & Wu et al. 2017 \\
\hline \multicolumn{2}{|c|}{$\begin{array}{l}\text { Molecular markers } \\
\text { By virtue of availability of the } \\
\text { genomic resources such as EST database, } \\
\text { genomic libraries, transcriptome assemblies, } \\
\text { genome sequences, etc. a large number of } \\
\text { molecular markers have been developed in } \\
\text { cucurbits (Bhawna et al 2015; Park et al. } \\
\text { 2015). The generated molecular markers being }\end{array}$} & \multicolumn{2}{|c|}{$\begin{array}{l}\text { utilized for genetic diversity assessment, } \\
\text { genetic mapping, tagging of important traits, } \\
\text { molecular assisted breeding (Harel-Beja et al. } \\
\text { 2010; Diaz et al. 2011; Ren et al. 2014). In } \\
\text { some cucurbits where genomic informations } \\
\text { are not available, the molecular markers have } \\
\text { been generated through cross-species } \\
\text { transferability (Table 2). }\end{array}$} \\
\hline
\end{tabular}

Table 2. List of molecular markers developed and utilized in cucurbits

\begin{tabular}{lccc}
\hline Crop & botanical name & Molecular markers & References \\
Bottle & Lagenaria siceraria & ISSR & Bhawna et al. 2014 \\
& & & \\
& & SSR & Bhawna et al. 2015 \\
& & RAPD & Decker-Walters et al. 2001 \\
Melon & Cucumis melo & SSR & Sarao et al. 2014 \\
& & RAPD & Srivastava et a., 2014 \\
Watermelon & Citullus lanatus & SSR & Bhawna et al. 2015 \\
& & EST-SSR & Fernandez-silva et al. 2008 \\
& & SSR & Patricia et al. 2004 \\
& & SCAR & Lin et al. 2009 \\
& & CAPS & Oumouloud et al. 2008 \\
Cucumber & C. sativus & SSR & Liu et val., 2016 \\
& & RAPD and SSR & Lu et al. 2018 \\
& & AFLP & Mujaju et al. 2010 \\
& & cDNA-AFLP & Sigva et al. 2015 \\
& & SSR & Bae et al. 2006 \\
& & EST-SSR & Fukino et al. 2008 \\
& & SRAP & Hu et al. 2010 \\
& & SSR & Meng et al. 2012 \\
& & RAPD & Watcharawongpaiboon et al. 2008 \\
& & Gwanama et al. 2000 \\
\hline
\end{tabular}




\section{Gene tagging/MAS breeding/QTLs}

Many simple sequence repeat (SSR) and sequence related amplified polymorphism (SRAP) markers have been developed in cucumber and watermelon. The genomic information has been used for the development of high density genetic maps and for whole-genome analysis, and identification of candidate genes for the important traits in cucumber (Meng et al. 2012). Several amplified fragment length polymorphism (AFLP) marker combinations were used for extensive genome analysis and identification of candidate genes in cucumber (Bae et al. 2006). Additionally, the molecular markers linked to the ZYMV resistance gene in cucumber ( $C$. sativus L.) using SRAP, SSR, and AFLP markers have been developed. Fusarium wilt, caused by Fusarium oxysporum f.sp. melonis, is one of the major diseases of melons (Cucumis melo L.) worldwide. Resistance genes to races 0 and 2 is conferred by the linked dominant gene Fom-I. Molecular markers linked to Fom$I$ would be useful for marker-assisted selection in breeding for resistance. This population was screened for resistance to race 2 Fusarium wilt. Bulk segregant analysis (BSA) was used to evaluate the RAPD and AFLP markers potentially linked to Fom-I. BSA was performed to identify markers linked to the genes conferring ZYMV resistance (Karsies et al. 2000). In this study, SSR marker was found to be tightly linked to the Zym-1 gene. Similarly, NIL populations were used to identify four RAPD markers associated with CMV resistance in melons. Two of the markers were mapped into two different linkage groups. Subsequently, the SCAR markers were developed from these associated RAPD markers to the CMV resistance in melon (Danin-Poleg et al. 2000). A highdensity genetic map was developed using SNPs in pepo (Cucurbita pepo) which provides an important insight into the quantitative trait loci (QTL) mapping and anchoring sequence to the scaffolds (Esteras et al. 2012).

Since 1994, several kinds of markers have been used to assess the genetic diversity of cucumber accessions including RAPD, AFLP, SCAR, SRAP, SSR (Bradeen et al. 2001; Fazio et al. 2003; Sun et al. 2006; Yuan et al. 2008). However, SNP markers were not available for cucumber in the past genomic era. With the rapid development of the NGS in cucumber, Zhu et al. (2016) developed a highdensity linkage map of cucumber using specific locus amplified fragment sequencing (SLAF), using 153 F2 populations. The highdensity genetic map composed of 3057 SLAFs, including 4475 SNPs on seven chromosomes spanned with $1061.19 \mathrm{cM}$. On the basis of this high-density genetic map, fifteen QTLs were detected for fruit length and fruit diameter in cucumber. Additionally, various important QTLs and horticultural traits associations such as disease resistance, sexual expression, formation of bisexual flowers, lateral branch, parthenocarpy, fruit shape, fruit warty and flesh thickness of fruit have also been identified in cucumber (Pan et al. 2005; Sakata et al. 2005; Sun et al. 2006; Li et al. 2009; Yang et al. 2014; Xu et al. 2015). These research interventions have been successfully used in cucumber marker-assisted 
selection breeding for tagging of agroeconomically important traits including fruit yield and quality. In China, northern Chinese type cucumber with many fruit spines is very popular, whereas in US countries processing type cucumber with a few spines is mainly cultivated as vegetable consumption. However, European countries consume the cucumber with smooth surface and almost no spine. The clarification of the inheritance and identification of molecular markers for the fruit spine density gene will provide a theoretical basis for breeding of fruit quality and lay the foundation for fine mapping and gene cloning. It was reported that several genes, such as s, s-2, s-3, ss, and ns, were related to the formation of cucumber fruit spines (Fanourakis \& Simon 1987). In this aspects, the tightly linked marker with trait governing of spines have been identified and a genetic map was constructed in cucumber (Zhang et al. 2016). The developed markers can be utilized for screening of the cucumber germplasm for trait of interest in future breeding programmes.

Genetic Engineering for fruit quality and yield enhancement

In the Cucurbitaceae family, transformation has been carried out in Cucumis spp., Cucurbita spp. and Citrullus spp. by using co-cultivation with Agrobacterium (Table 3). Some improved protocols have been lately reported in melon (Bezirganoglu et al. 2014), cucumber (Wang et al. 2015) and watermelon (Liu et al. 2016). In the cucurbitaceous species, an efficient regeneration procedure via somatic embryogenesis from embryogenic calli, developed from leaf explants, has also been recently published (Vinoth \& Ravindhran, 2015). Attempts to develop in planta transformation methods (either via pollen tube or microinjection of the shoot apical meristem) have been made in watermelon and cucumber (Chen et al. 2016). The genetic and molecular basis of shoot regeneration helped in understanding the regeneration ability from leaf explants in cucumber (Nadolska-Orczyk \& Malepszy 1989). Simultaneously, distinct expression profiles of WUSCHEL-related homeobox (WOX) genes have been studied and reported with different regeneration abilities in watermelon (Zhang et al. 2015). Even a large number of genetic transformation protocols have been developed in cucurbits. However, the current protocols of genetic transformation are not high throughput and remain less important for validation of candidate genes for particular functions. Therefore, there is need to develop high throughput genetic transformation protocols in cucurbits.

Cucumber (Cucumis sativus L.) is one of the most popular vegetables worldwide. The first transformation in cucumber through an Agrobacterium-mediated system was described two decades ago (Trulson et al. 1986). In addition to the marker and reporter genes, various types of transgenes with agronomic potential have been introduced into cucumber. The enhanced biotic resistance was observed after introduction of cucumber mosaic virus coat protein (CMV-cp) gene (Nishibayashi et al. 1996), zucchini green mottle mosaic virus coat protein (ZGMMVcp) gene and chitinase genes (Tabei et al. 
1998). Additionally, the introduction of DHN10 gene was also associated with a slightly enhanced tolerance to abiotic stresses (Yin et al. 2005). The transformation of thaumatin II cDNA construct in cucumber enhanced the sweetness in fruits (Szwacka et al. 2002), whereas $m S O D 1$ gene caused higher level of superoxide dismutase (SOD) and might be useful as a functional cosmetic material (Lee et al. 2003). The genetic transformation of $U G T$ and $A C B$ genes resulted in an increased yield (Salyaev et al. 2002). Similarly, introduction of iaaM gene led to parthenocarpic fruit production in cucumber (Yin et al. 2006).

Table 3. List of transgenic developed in cucurbits

\begin{tabular}{|c|c|c|c|c|}
\hline Crop & Gene & & Trait & References \\
\hline Watermelon & $\begin{array}{l}\text { WUSCHEL-related } \\
\text { (WOX) }\end{array}$ & homeobox & Regeneration & Zhang et al. 2015 \\
\hline Cucumber & CMV-cp & & Virus resistance & $\begin{array}{l}\text { Nishibayashi et al. } \\
1996\end{array}$ \\
\hline \multirow[t]{2}{*}{ Cucumber } & ZGMMV-cp & & Virus resistance & Lee et al. 2002 \\
\hline & Chitinase & & Virus resistance & Tabei et al. 1998 \\
\hline Cucumber & Thaumatin II & & Sweetening & Szwacka et al. 2002 \\
\hline Cucumber & mSOD1 & & Cosmetic materials & Lee et al. 2003 \\
\hline Cucumber & DHN10 & & abiotic stresses & Yin et al. 2005 \\
\hline
\end{tabular}

\section{Genome editing}

The genetic modifications through breeding of crop plants have long been used to improve the yield and quality which is time consuming and labor intensive. However, precised genome editing tools could be a very useful and effective supplementary approach for improvement of crop plants by targeted gene or locus modification in the genome of an organism. This approach is mostly effective against biotic stress because the biological interaction between plant and disease causing biological agents can be disturbed at particular site. Subsequently, numerous genome editing techniques including zinc finger nucleases (ZFNs) and transcription activator-like effector nucleases (TALENs) have been successfully employed in various crop horticultural crops including cucurbitaceous crops (Koltun et al. 2018; Reem \& Eck 2019). In the current era of genomics and biotechnology, clustered regularly interspaced short palindromic repeats (CRISPR)/Cas9 (CRISPR-associated protein 9) has become the choice of interest for genome editing and it has apparently utilized for crop improvement in cucurbitaceous crops (Tian et al. 2017). Whole cucurbits are severely affected by various biotic stresses including virus infection worldwide. In this context, targeted mutagenesis using CRISPR/CAS9 approach was deployed in cucumber and developed non-transgenic exhibiting resistance against cucumber vein yellowing virus (ipomovirus). This study non-transgenic virus resistance plants were produced by disruptbing eIF4E gene. The generated non-transgenic plants exhibited partial resistance against ipomovirus and two potyviruses such as Papaya ring spot mosaic virus- $\mathrm{W}$ and Zucchini yellow mosaic virus. Additionally, the phytoene desaturase gene of watermelon (CIPDS) was mutated using 
CRISPR/CAS9 approach very recently (Tian et al. 2017). By disturbing the function of this gene, albino phenotype was created in watermelon. Thus this CRISPR/CAs9 based foundation research in watermelon could be useful for understanding the functions of other genes of interest.

\section{Future prospective}

Since the mostly cucurbits are grown in arid and semi-arid region therefore they are very hardy against the environmental factors. For examples, the deep root system of bitter apple (Citrullus colosynthes) makes the basis to understand the mechanism behind the root architecture of the plant. Similarly, in the desert region various such type of crops are flourishing under the adverse condition. Additionally, in some cucurbits, antinutritional factor have been reported. The silencing of genes encoding the antinutritional product can be initiated for better quality food. In addition to this, physiological, biochemical and molecular understanding of the mechanisms of adaptive behavior of cucurbitaceous crop in very hot and dry environment is making the future thrust area in cucurbit research. The targeted mutagenesis using CRISPR/CAS9 technology is very recent breakthrough in biotechnology. Therefore, these are a huge scope of using genome editing approaches in cucurbits for crop improvement particularly for disease resistance and fruit quality parameters.

\section{Conclusions}

In nut shell, the cucurbit crops have been exploited sufficiently at molecular level to develop the genomic tools and carrying the biotechnological interventions. However, still it required more intentions to refine the study. The developed technologies so far in cucurbits may useful to enhanced utilization of the cucurbitaceous germplasms for sustainable development of the horticulture.

\section{References}

Ando K \& Grumet R. 2010. Transcriptional profiling of rapidly growing cucumber fruit by 454-pyrosequencing analysis. Journal of the American Society for Horticultural Science, 135:291-302.

Bae KM, Kwon YS, Cho IH \& Yi SI. 2006. Use of cDNA-AFLP for transcript profiling in narrow genetic pools; for example, cucumber (Cucumis sativus L.). Plant Breeding, 125: 488-492.

Bezirganoglu I, Hwang SY, Hwang SY, Shaw JF \& Fang TJ. 2014. Efficient production of transgenic melon via Agrobacterium-mediated transformation. Genetics and Molecular Research, 13:3218-27.

Bhawna, Abdin MZ, Arya L, Chet Ram, Sureja AK \& Verma M. 2015. Development of novel gene-based microsatellite markers for robust genotyping purposes in Lagenaria siceraria. Scientia Horticulturae, 191:15-24.

Bhawna, Abdin MZ, Arya L, Dipnarayan S, Sureja AK, Chitra P \& Verma M. 2014. Population structure and genetic diversity in bottle gourd [Lagenaria siceraria (Mol.) Standl.] accession from India assessed by ISSR markers. Plant Systematics and Evolution, 300:767-773. Blanca J, Canizares J, Roig C, Ziarsolo P, Nuez F \& Pico B. 2011. Transcriptome characterization \& high throughput SSRs \& SNPs discovery in Cucurbita 
pepo (Cucurbitaceae). BMC Genomics, 12:104.

Bradeen JM, Staub IE, Wye C, Antonise R, \& Peleman J. 2001. Towards an expanded and integrated linkage map of cucumber (C. sativus L.). Genome, 44:111-119.

Chen H, Sun J, Li S, Cui Q, Zhang H, Xin F, Wang $\mathrm{H}$, Lin T, Gao D, Wang S, Li X, Wang D, Zhang Z, Xu Z \& Huang S. 2016. An ACC oxidase gene essential for cucumber carpel development. Molecular Plant, 9:1315-1327.

Clepet C, Joobeur T, Zheng Y, Jublot D, Huang M, Truniger V, Boualem A, Hernandez-Gonzalez ME, DolcetSanjuan R, Portnoy V, Mascarell-Creus A, Caño-Delgado A, Katzir N, Bendahmane A, Giovannoni JJ, Aranda MA, Garcia-Mas J \& Fei Z. 2011. Analysis of expressed sequence tags generated from full-length enriched cDNA libraries of melon. $B M C$ Genomics, 12:252.

Cucurbit genomic database available at http://cucurbitgenomics.org.

Danin-Poleg Y, Tzuri G, Reis N, Karchi Z \& Katzir N. 2000. Search for molecular markers associated with resistance to viruses in melon. Acta Horticulturae, 510:399-404.

Decker-Walters D, Staub J, Lopez-Sese A \& Nakata E. 2001. Diversity in landraces \& cultivars of bottle gourd (Lagenaria siceraria; Cucurbitaceae) as assessed by random amplified polymorphic DNA. Genetic Resources and Crop Evolution, 48:369-380.

Deleu W, Esteras C, Roig C, González-To M, Fernández-Silva I, Gonzalez-Ibeas D, Blanca J, Aranda MA, Arús P, Nuez F, Monforte MJ, Belén Picó M \& GarciaMas J. 2009. A set of EST-SNPs for map saturation and cultivar identification in melon. BMC Plant Biology, 9:90.
Diaz A, Fergany M, Formisano G, Ziarsolo P, Blanca J, Fei Z, Staub JE, Zalapa JE, Cuevas HE, Dace G, Oliver M, Boissot N, Dogimont C, Pitrat M, Hofstede R, van Koert P, Harel-Beja R, Tzuri G, Portnoy V, Cohen S, Schaffer A, Katzir $\mathrm{N}, \mathrm{Xu} \mathrm{Y}$, Zhang $\mathrm{H}$, Fukino $\mathrm{N}$, Matsumoto S, Garcia-Mas J \& Monforte AJ. 2011. A consensus linkage map for molecular markers \& Quantitative Trait Loci associated with economically important traits in melon (Cucumis melo L.). BMC Plant Biology, 11:111.

Esteras C, Gómez P, Monforte AJ, Blanca J, Vicente-Dólera N, Roig C, Nuez F \& Pico B. 2012. High-throughput SNP genotyping in Cucurbita pepo for map construction and quantitative trait loci mapping. BMC Genomics, 13:8.

Fanourakis, N.E. \& P.W.Simon, 1987. Inheritance and linkage studies of the fruit epidermal structure in the cucumber. J. Hered. 78: 369-371.

FAOSTAT 2015: www.fao.org/faostat.

Fazio G, Staub JE, \& Stevens MR. 2003. Genetic mapping and QTL analysis of horticultural traits in cucumber (Cucunus sativus L.) using recombinant inbred lines. Theoretical \& AppIied Genetics, 107:864-874.

Fernandez-silva I, Eduardo I, Blanca J, Esteras C, Pico B, Nuez F, Arus P, Garcia-Mas J \& Monforte AJ. 2008. Bin mapping of genomic \& EST-derived SSRs in melon (Cucumis melo L.). Theoretical and Applied Genetics, 118:139-150.

Fukino N, Yoshioka Y, Kubo N, Hirai M, Sugiyama M, Sakata Y \& Matsumoto S. 2008. Development of 101 novel SSR markers \& construction of an SSR-based genetic linkage map in cucumber (Cucumis sativus L.). Breed Science, 58:475-483. 
Guo S, Liu J, Zheng Y, Huang M, Zhang M, Gong G, He H, Ren Y, Zhong S, Fei Z \& $\mathrm{Xu}$ Y. 2011. Characterization of transcriptome dynamics during watermelon fruit development: sequencing, assembly, annotation \& gene expression profiles. $B M C$ Genomics, 12:454.

Guo S, Zhang J, Sun H, Salse J, Lucas WJ, Zhang $\mathrm{H}$, Zheng $\mathrm{Y}$, Mao L, Ren $\mathrm{Y}$, Wang Z, Min J, Guo X, Murat F, Ham BK, Zhang Z, Gao S, Huang M, Xu Y, Zhong S, Bombarely A, Mueller LA, Zhao $\mathrm{H}$, He $\mathrm{H}$, Zhang $\mathrm{Y}$, Zhang Z, Huang S, Tan T, Pang E, Lin K, Hu Q, Kuang H, Ni P, Wang B, Liu J, Kou Q, Hou W, Zou X, Jiang J, Gong G, Klee $\mathrm{K}$, Schoof H, Huang Y, Hu X, Dong S, Liang D, Wang J, Wu K, Xia Y, Zhao X, Zheng Z, Xing M, Liang X, Huang B, Lv T, Wang J, Yin Y, Yi H, Li R, Wu M, Levi A, Zhang X, Giovannoni JJ, Wang J, Li Y, Fei Z \& Xu Y. 2013. The draft genome of watermelon (Citrullus lanatus) \& resequencing of 20 diverse accessions. Nature Genetics, 45:51-58.

Guo S, Zheng Y, Joung JG, Liu S, Zhang Z, Crasta OR, Sobral BW, Xu Y, Huang S \& Fei Z. 2010. Transcriptome sequencing \& comparative analysis of cucumber flowers with different sex types. BMC Genomics, 11:384.

Gwanama C, Labuschagne MT \& Botha AM. 2000. Analysis of genetic variation in Cucurbita moschata by random amplified polymorphic DNA (RAPD) markers. Euphytica, 113:19-24.

Harel-Beja R, Tzuri G, Portnoy V, LotanPompan M, Lev S, Cohen S, Dai N, Yeselson L, Meir A, Libhaber SE, Avisar E, Melame T, van Koert P, Verbakel H, Hofstede R, Volpin H, Oliver M, Fougedoire A, Stalh C, Fauve J, Copes B, Fei Z, Giovannoni J, Ori N,
Lewinsohn E, Sherman A, Burger J, Tadmor Y, Schaffer AA \& Katzir N. 2010. A genetic map of melon highly enriched with fruit quality QTLs \& EST markers, including sugar \& carotenoid metabolism

Theoretical and Applied Genetics, 121:511-33.

$\mathrm{Hu}$ J, Li J, Liang F, Liu L \& Si S. 2010. Genetic relationship of a cucumber germplasm collection revealed by newly developed EST-SSR markers. Journal of Genetics, 3089: 28-32.

$\mathrm{Hu}$ JB, Zhou XY \& Li JW. 2010. Development of novel EST-SSR markers for cucumber (Cucumis sativus) and their transferability to related species. Scientia Horticulturae, 125: 534-538.

Karsies T, Dean R \& Thomas C. 2000. Toward the development of molecular markers linked to race 2 fusarium wilt resistance in melon (cucumis melo 1.). Acta Horticulturae, 510:415-420.

Koltun A, Corte LED, Mertz-Henning LM \& Gonçalves LSA. 2018. Genetic improvement of horticultural crops mediated by CRISPR/Cas: a new horizon of possibilities. Horticultura Brasileira, 36: 290-298.

Kwon YS. 2013. Use of EST-SSR markers for genetic characterization of commercial watermelon varieties and hybrid seed purity testing. Seed Science and Technology, 41: 245-256.

LEE GP, KIM CS, RYU KH \& RARK KW 2002. Agrobacterium-mediated transformation of Cucumis sativus expressing the coat protein gene of zucchini green mottle mosaic virus (ZGMMV). XXVIth International Horticultural Congress, Metro Toronto Convention Centre, Symposium 11, Asian plants with unique horticulture 
potential, genetic resources, cultural practices and utilization, S11-P-11: 300.

Lee HS, Kwon EJ, Kwon SY, Jeong YJ, Lee EM, Jo MH, Kim HS, Woo IS, Shinmyo A, Yoshida K, Kwak SS. 2003. Transgenic cucumber fruits that produce elevated level of an anti-aging superoxide dismutase. Molecular Breeding, 11: 213.

Li Z, Huang S, Liu S, Pan J, Zhang Z, Tao Q, et al. 2009. Molecular isolation of the $M$ gene suggests that a conserved-residue onversion induces the formation of bisexual flowers in cucumber plants. Genetics, 182:1381-1385.

Li Z, Zhang Z, Yan P, Huang S, Fei Z \& Lin K. 2011. RNA-Seq improves annotation of protein-coding genes in the cucumber genome. BMC Genomics, 12: 540.

Lin Y, Chen KS, Liou TD, Huang JW \& Chang PFL. 2009. Development of a molecular method for rapid differentiation of watermelon lines resistant to Fusarium oxysporum f. sp. Niveum. Botanical Studies, 50:273-280.

Liu S, Gao P, Zhu Q, Luan F, Davis AR \& Wang X. 2016. Development of cleaved amplified polymorphic sequence markers \& a CAPS-based genetic linkage map in watermelon (Citrullus lanatus [Thunb.] Matsum. \& Nakai) constructed using whole-genome resequencing data. Breeding Science, 66: 244-259.

Lu X, Adedze YMN, Chofong GN, Gandeka M, Deng Z, Teng L, Zhang X \& Sun G. 2018. Identification of high-efficiency SSR markers for assessing watermelon genetic purity. Journal of Genetics, 97:1295-1306.

Meng H, Chen S, Cheng Z, Chai D \& Li Y. 2012. SRAP markers for fruit shape in cucumber. Pakistan Journal of Botany, 44:1381-1384.
Mujaju C, Sehic J, Werlemark G, GarkavaGustavsson L, Fatih M \& Nybom H. 2010. Genetic diversity in watermelon (Citrullus lanatus) landraces from Zimbabwe revealed by RAPD and SSR markers. Hereditas, 147: 142-153.

Nadolska-Orczyk, A \& Malepszy S. 1989. In vitro culture of Cucumis sativus $\mathrm{L}$. Theoretical \& Applied Genetics, 78: 836.

Nishibayashi S, Kaneko H \& Hayakawa $\mathrm{T}$. 1996. Transformation of cucumber (Cucumis sativus L.) plants using Agrobacterium tumefaciens and regeneration from hypocotyl explants. Plant Cell Reports, 15: 809-814.

Oumouloud A, Arnedo-Andres MS, Gonzalez-Torres R \& Alvarez JM. 2008. Development of molecular markers linked to the Fom-1locus for resistance to Fusarium race 2 in melon. Euphytica, 164: 347.

Pan JS, Wang G, Li XZ, He HL, Wu AZ \& Cai R. 2005. Construction of a genetic map with SRAP markers and localization of the gene responsible for the first-flower-node trait in cucumber (Cucumis sativus L.). Progress in Natural Science, 15:407-413.

Park G, Kim N \& Park Y. 2015. Genomics and molecular markers for major cucurbitaceae crops. Journal of Life Science, 25:1059-1071.

Patricia SR, Tulio CDLL, Rodrigo LT, Glaucia SCB, Jose AB \& Marcio EF. 2004. Development of microsatellite markers from an enriched genomic library for genetic analysis of melon (Cucumis melo L.). BMC Plant Biology, 18: 4-9.

Qi J, Liu X, Shen D, Miao H, Xie B, Li X, Zeng P, Wang S, Shang Y, Gu X, Du Y, Li Y, Lin T, Yuan J, Yang X, Chen J, Chen H, Xiong X, Huang K, Fei Z, Mao 
L, Tian L, Städler T, Renner SS, Kamoun S, Lucas WJ, Zhang Z \& Huang S. 2013. A genomic variation map provides insights into the genetic basis of cucumber domestication \& diversity. Nature Genetics, 45:15101515.

Reem NT \& Van Eck J. 2019. Application of CRISPR/Cas9-mediated gene editing in tomato. In: Qi Y. (eds) Plant genome editing with CRISPR systems. Methods in molecular biology, vol. 1917. Humana Press, New York, NY.

Ren Y, McGregor C, Zhang Y, Gong G, Zhang H, Guo S. Sun H, Cai W, Zhang J \& Xu Y. 2014. An integrated genetic map based on four mapping populations $\&$ quantitative trait loci associated with economically important traits in watermelon (Citrullus lanatus). BMC Plant Biology, 14: 33.

Ruggieri V, Alexiou KG, Morata J, Argyris J, Pujol M, Yano R, Nonaka S, Ezura H, Latrasse D, Boualem A, Benhamed M, Bendahmane A, Cigliano RA, Sanseverino W, Puigdomènech P, Casacuberta JM \& Garcia-Mas J. 2018. An improved assembly \& annotation of the melon (Cucumis melo L.) reference genome. Scientific Reports, 8: 8088

Sakata Y, Kubo N, Morishita M, Kitadani E, Sugiyama M \& Hirai M. 2005. QTL analysis of powdery mildew resistance in cucumber (Cucumis sativus L.). Theoretical \& AppIied Genetics, 112:243-250.

Salyaev RK, Rekoslavskaya NI \& Mapelli S. 2002. Increase of productivity in transgenic plants with introduced genes UGT, ACB and ACP. 13 ${ }^{\text {th }}$ Congr. of the Federation of European Societies of Plant Physiology, Crete, Greece. Abstract, Section 8, Biological Applications: 49.
Sarao NK, Pathak M, Kaur N \& Kaur K. 2014. Microsatellite-based DNA fingerprinting \& genetic diversity of bottle gourd genotypes. Plant Genetic Resources: Characterization and Utilization, 12: 156-159.

Şigva HO, Firat AF, Hazarhun G \& Ipek A. 2015. Development of AFLP markers associated with zucchini yellow mosaic virus resistance in cucumber (Cucumis sativus L.). Turkish Journal of Botany, 39: 982-987.

Srivastava D, Khan NA, Shamim M, Yadav P, Pandey P \& Singh KN. 2014. Assessment of the genetic diversity in bottle gourd (Lagenaria siceraria [Molina] Standl.) genotypes using SDSPAGE \& RAPD markers. National Academy Science Letters, 37: 155-161.

Sun H, Wu S, Zhang G, Jiao C, Guo S, Ren Y, Zhang J, Zhang H, Gong G, Jia Z, Zhang F, Tian J, Lucas WJ, Doyle JJ, Li H, Fei Z \& Xu Y. 2017. Karyotype stability \& unbiased fractionation in the paleoallotetraploid Cucurbita genomes. Molec ular Plant, 10:1293-1306.

Sun Z, Staub JE, Chung SM \& Lower RL. 2006. Identification and comparative analysis of quantitative trait loci associated with parthenocarpy in processing cucumber. Plant Breeding, 125:281-287.

Szwacka M, Krzymowska M, Osuch A, Kowalczyk ME \& Malepszy S. 2002. Variable properties of transgenic cucumber plants containing the thaumatin II gene from Thaumatococcus daniellii. Acta Physiologiae Plantarum, 24:173-185.

Tabei Y, Kitade S, Nishizawa Y, Kikuchi N, Kayano T, Hibi T \& Akutsu K. 1998. Transgenic cucumber plants harboring a rice chitinase gene exhibit enhanced 
resistance to gray mold (Botrytis cinerea). Plant Cell Reports, 17: 159.

Tian S, Jiang L, Gao Q, Zhang J, Zong M, Zhang H, Ren Y, Guo S, Gong G, Liu F \& Xu Y. 2017. Efficient CRISPR/Cas9based gene knockout in watermelon. Plant Cell Reports, 36:399-406.

Trulson AJ, Simpson RB \& Shahin EA. 1986. Transformation of cucumber (Cucumis sativus L.) plants with Agrobacterium rhizogenes. Theoretical and Applied Genetics, 73: 11-15.

Verma M \& Arya L. 2015. Development of EST-SSRs in watermelon (Citrullus lanatus var. lanatus) and their transferability to Cucumis spp. Journal of Horticultural Science and Biotechnology, 83: 732-736.

Vinoth A \& Ravindhran R. 2015. Reduced hyperhydricity in watermelon shoot cultures using silver ions. In Vitro Cellular \& Developmental Biology Plant, 51: 258-264.

Wang S, Ku SS, Ye X, He C, Kwon SY \& Choi PS. 2015. Current status of genetic transformation technology developed in cucumber (Cucumis sativus L.). Journal of Integrative Agriculture, 14:469-482.

Watcharawongpaiboon N \& Chunwongse J. 2008. Development \& characterization of microsatellite markers from an enriched genomic library of cucumber (Cucumis sativus L). Plant Breeding, 127: 74-81.

Wechter WP, Levi A, Harris KR, Davis AR, Fei Z, Katzir N, Giovannoni JJ, SalmanMinkov A, Hernandez A, Thimmapuram J, Tadmor Y, Portnoy V \& Trebitsh T. 2008. Gene expression in developing watermelon fruit. BMC Genomics, 9: 275.

Wu S, Shamimuzzaman M, Sun H, Salse J, Sui X, Wilder A, Wu Z, Levi A, Xu Y,
Ling KS \& Fei Z. 2017. The bottle gourd genome provides insights into Cucurbitaceae evolution \& facilitates mapping of a papaya ringspot virus resistance locus. The Plant Journal, 92: 963-975.

Xu P, Wu X, Luo J, Wang B, Liu Y, Ehlers JD, Wang S, Lu Z \& Li G. 2011. Partial sequencing of the bottle gourd genome reveals markers useful for phylogenetic analysis and breeding. BMC genomics, 12: 467.

Xu X, Xu R, Zhu B, Yu T, Qu W, Lu L, et al. 2015. A high-density genetic map of cucumber derived from Specific Length Amplified Fragment sequencing (SLAFseq). Frontiers in Plant Science, 5:768.

Yang XQ, Zhang WW, He HL \& Nie JT. (2014). Tuberculate fruit gene $\mathrm{Tu}$ encodes a $\mathrm{C} 2 \mathrm{H} 2$ zinc finger protein that is required for the warty fruit phenotype in cucumber (Cucumis sativus L.). Plant Journal, 78:1034-1046.

Yin Z, Malinowski R, Ziokowska A, Sommer H, Plider W \& Malepszy S. 2006. The DefH9- iaaM containing construct efficiently induces parthenocarpy in cucumber. Cell Molecular Biology Letter, 11:279-90.

Yin Z, Pląder W, Wiśniewska A, Szwacka M \& Malepszy S. 2005. Transgenic cucumber-a current state. Folia Horticulturae, 17:73-90.

Yu C, Dong W, Zhan Y, Huang ZA, Li Z, Kim IS \& Zhang C. 2017. Genome-wide identification \& expression analysis of CLLAX, CLPIN \& CLABCB genes families in Citrullus lanatus under various abiotic stresses \& grafting. $B M C$ Genetics, 18: 33.

Yuan XJ, Li XZ, Pan JS, Wang G, Jiang S, Li X H, et al. 2008. Genetic linkage map construction and location of QTLs for 
fruit-related traits in cucumber. Plant Breeding, 127:180-188.

Zhang N, Huang X, Bao Y, Wang B, Liu L, Dai L, Chen J, An X, Sun Y \& Peng D. 2015. Genome-wide identification and expression profiling of WUSCHELrelated homeobox (WOX) genes during adventitious shoot regeneration of watermelon (Citrullus lanatus). Acta Physiologiae Plantarum, 37:224.

Zhang N, Huang X, Bao Y, Wang B, Zeng H, Cheng W, Tang M, Li Y, Ren J \& Sun Y. 2017. Genome-wide identification of SAUR genes in watermelon (Citrullus lanatus). Physiology \& Molecular Biology of Plants, 23: 619-628.

Zhang S, Liu S, Miao H, Wang M, Liu P, Wehner TC \& Gu X. 2016. Molecular Mapping \& Candidate Gene Analysis for Numerous Spines on the Fruit of Cucumber. Journal of Heredity, 107: 471-477.
Zheng Y, Wu S, Bai Y, Sun H, Jiao C, Guo S, Zhao K, Blanca J, Zhang Z, Huang S, $\mathrm{Xu}$ Y, Weng Y, Mazourek M, Reddy UK, Ando K, McCreight JD, Schaffer AA, Burger J, Tadmor Y, Katzir N, Tang X, Liu Y, Giovannoni JJ, Ling K, Wechter WP, Levi A, Garcia-Mas J, Grumet R \& Fei Z. 2018. Cucurbit Genomics Database (CuGenDB): a central portal for comparative and functional genomics of cucurbit crops. Nucleic Acids Research, doi: 10.1093/nar/gky944.

Zhu WY, Huang L, Chen L, Yang JT, Wu JN, Qu ML, Yao DQ, Guo CL, Lian HL, He HL, Pan JS \& Cai R. 2016. A highdensity genetic linkage map for cucumber (Cucumis sativus L.): Based on Specific Length Amplified Fragment (SLAF) Sequencing \& QTL analysis of fruit traits in cucumber. Frontiers in Plant Science, 7: 437. 